\title{
Satisfaction and protection of individual mobile telecommunications consumers.*
}

\author{
Covadonga Gijón Tascón, \\ Universidad Complutense, Spain. \\ Teresa Garín-Muñoz, \\ UNED, Spain. \\ Teodosio Pérez-Amaral, \\ Universidad Complutense, Spain. \\ Rafael López Zorzano, \\ Universidad Complutense, Spain.
}

September 2012

\begin{abstract}
The focus of this paper is to measure customer satisfaction among private individual consumers of mobile telecommunications in Spain and the factors associated with this. Two novelties found in this paper are a focus on individual consumers and the usage of rich data to convey high quality statistical information. Our data allow us to discriminate by operator, region of residence (Autonomous Regions and provinces), gender, age, and educational level, among others. Specifically, we formulate relationships between different aspects of satisfaction and its determinants. We specify econometric models and estimate them using survey data on 4,953 individual consumers. Our results indicate that customers are less satisfied with larger carriers like Movistar and Vodafone, and are more satisfied with smaller and newer operators. We also measure the contribution of each of the aspects of satisfaction to the overall satisfaction by specifying individual equations for each one of them and estimating the importance of each of its determinants. Complaints about billing, difficulty in obtaining the required information and coverage are the major contributors to consumer (dis)satisfaction.
\end{abstract}

Key words and phrases: Consumer satisfaction, consumer protection, mobile telecommunications, individual private consumers, survey data, econometric models.

JEL Classifications: C21, D12, L52, L96.

\footnotetext{
* The authors wish to acknowledge the financial support of the Ministerio de Economía e Innovación, through project ECO2008-06191, and the Comunidad de Madrid, Spain. Thanks are due to Jeffrey Wooldridge for comments and suggestions. Corresponding author: Teodosio Pérez-Amaral, teodosio@ccee.ucm.es
} 


\section{Introduction}

The liberalization and re-regulation of telecommunications in many countries since the 1980s has been regarded as successful in many accounts. The main focus has been to regulate the relationships between competing firms, between regulators and firms, and between the regulators themselves.

The explicit aim of these regulations was to improve the welfare of customers, both individuals and firms. However customer complaints are abundant and complaints about mobile telecommunications services are numerous in most industrialized countries (El País, 2012).

Since telecommunications markets are now more mature it may be time to focus directly on the relationships between firms and customers. Here we focus on individual private consumers.

This paper is part of an ongoing project on the protection of individual mobile consumers. The main research questions of the project are:

a. Whether, and to what extent, individual consumers of mobile telecommunications are subject to dubious practices by mobile operators, possibly due to market failures (López et al. 2012), and

b. Whether improved regulation can increase the efficiency of the industry and the welfare of individual telecommunications consumers.

This paper aims to contribute to the second research question mentioned above. To do this we analyze the satisfaction of private individual consumers of mobile telecommunications in Spain and the factors associated with it.

We have found few studies with a similar focus on individual consumers. In Spain, somewhat related studies include those by Álvarez and Caballero (1995), García Zaballos and Escribano (2002), González et al. (2003), Herguera (2001), Jarillo (1995), Osa (2001) and Soto et al. (2003), which focus on mobile operators and regulators' perspectives but not on individual consumers.

We also mention the website (http://www.usuariosteleco.es/) of the Ministry of Industry, which is a regulator of telecoms in Spain, and where user complaints are dealt with. A recent survey on the satisfaction of business customers was performed by the 
Comisión del Mercado de las Telecomunicaciones, CMT, (2011), and there is also a survey called "Satisfacción de Usuarios de Servicios de Telecomunicación" by the Centro de Investigaciones Sociológicas (CIS), Spain (2009), that we use as the main data source in this paper.

In other countries, and from the point of view of mobile operators, we mention Dedrick et al. (2011), Lee (2011), Lescop and Isckia (2010), Ono and Tang (2010), Song (2010), and Zhang and Liang (2011), among others. They analyze regulation problems, information asymmetries, and competition structures of mobile network services.

Other papers that deal with these topics from the point of view of the industrial organization are Karacuka et al. (2011), Lam (2010), and Symeou (2011), which examines fixed-to-mobile traffic substitution for consumers and price elasticities for the market. In comparison, Davies et al. (2008), Diehl (2010), Palcic and Reeves (2010), and Renda (2010) adopt the point of view of the regulator when analyzing access-based competition and investments in new infrastructures.

In this paper we adopt the point of view of individual private consumers, rather than business consumers because, in general, the latter's behavior differs from that of individual consumers and a unified treatment would not be useful. We intend to analyze individual satisfaction and its determinants of residential consumers of mobile services.

Given that satisfaction is related to quality, it should de defined before studying consumer satisfaction. Quality has many different definitions and no one is universally accepted (Hardie and Walsh, 1994). Service quality is defined in Parasuraman et al. (1985) as the discrepancy between a customer's expectation of a service and the customer's perception of the service offerings. They propose SERVQUAL, a model designed to measure service quality according to ten different dimensions of quality. Ladhari (2009) recommends to adapt the model to the specifics or the service being measured in order to ensure valid and reliable results, which is what we do here using the measurements of satisfaction provided by our survey. In this paper we go one step further by focusing on analyzing the determinants of satisfaction by individual customers.

The rest of the paper is organized as follows: section 2 contains the description of the data; section 3 includes different equations of customer satisfaction. Section 4 presents 
several equations related to consumer satisfaction and complaints, while section 5 concludes.

\section{The Data.}

In order to analyze the satisfaction of consumers, we will use a representative survey for the entire country with data on 4,953 individual consumers: "Satisfacción de Usuarios de servicios de telecomunicación", conducted by the Centro de Investigaciones Sociológicas of Spain (CIS, 2009). The center is an official government body that produces high-quality statistics that are well-suited to our analysis. The CIS micro-data have been made available through the Internet. Although this is the first time that it's been used, the basic tabulation of the results is available on the CIS website. The survey is about individual private consumer satisfaction and includes questions about sociodemographics, different operators, satisfaction with fixed and mobile telephony, Internet, complaint resolutions, etc.

The data are representative nationwide, by province and Autonomous Community and also by gender, age and major telecommunications carrier, thus making them appropriate for the analysis that we perform in our research. There is an alternative source of data for quality, from the Ministerio de Industria (2012), but its reliability is limited since it is elaborated with self reported data.

\section{[Figure 1 goes here]}

We can also differentiate by operator, as seen in Figure 1 that shows the respective market shares of Movistar (48.0\%), Vodafone (30.3\%), Orange (18.7\%), Yoigo (1.7\%), and Mobile virtual operators (1.3\%).

\section{[Figure 2 goes here]}

In Figure 2 we observe histograms of 10 measures of satisfaction related to relevant aspects of mobile telephony services. The first panel shows overall satisfaction while the rest correspond respectively to the satisfactions about cost, communication quality, customer care, bill clarity, adequacy of rates, coverage, easy-to-find rates and offers, convenience for acquiring new handsets, and complementary services, respectively. We observe substantial variability across the histograms of each measure of satisfaction. 
While all of them have uni-modal and asymmetric empirical distributions, the modes are generally different, as are the patterns of asymmetry, as seen in Table 1.

\section{[Table 1 goes here]}

2.a. Descriptive statistics of selected variables.

The descriptive statistics of the different measures of satisfaction with different aspects of mobile telephony are given in Table 1 . Note that the averages of the different measures of satisfaction vary between 5.62 and 7.18, while the standard errors vary between 1.78 and 2.25, which indicate relatively large variations around the averages.

This suggests that it may be worthwhile to perform individual analyses for each of one of the measures of satisfaction.

\section{2.b. Scatter plots.}

In Figures 3 and 4, we present some histograms and scatter plots that offer insight into the relationships present in the sample: Overall satisfaction vs. possible determinants such as age, education and expenditure; and Overall satisfaction by operators.

\section{[Figures 3 and 4 go here]}

\section{Empirical models for customer satisfaction of mobile consumers.}

In this section we present the results of the various models of customer satisfaction that we have developed. With these models we analyze the determinants of satisfaction and their quantification. Specifically we present ten models. One of them relates to overall satisfaction while the rest of them relate satisfaction with the following specific determinants: cost, communications quality, customer care, bill clarity, adequacy of rates, coverage, easily find rates and offers, easily acquire new handsets, and complementary services.

The observed measures of satisfaction vary between 1 and 10 in our sample. Here, in order to approximate unknown relationships, we use general linear models estimated by generalizations of least squares methods. While data on satisfaction are somewhat 
ordinal, we treat them as cardinal, assuming that the differences between adjacent values of the satisfaction indices are constant across values of the index ${ }^{1}$.

In this paper we assume a linear relationship between satisfaction and its possible determinants, and therefore write models which are linear both in the explanatory variables and in the parameters. This type of model has several advantages, specifically the direct interpretability of the estimated coefficients.

An alternative model is ordered probit (or logit). Wooldridge (2010) recommends starting with linear regression and, if necessary, continuing with ordered probit. This approach has been used by Peel et al. (1998) and Papke (1998). Moreover, Garin et al. (2012), also use OLS and ordered probit. In this case, as in the previously mentioned cases, the results are similar to those of linear regression in terms of signs and significance of coefficients, and in most cases they obtain substantially similar fits to linear regression.

\section{[Table 2 goes here]}

\section{3.a. Model M0. Overall satisfaction and its components.}

We start with a model that relates overall satisfaction to each of its 9 components. It is reasonable to hypothesize that total satisfaction will be related to each of the components of satisfaction, although the relationship includes an error term, since it will not be exact or exhaustive. However, the weight of each of the components on the overall satisfaction is not known a priori. Table 2 summarizes the estimation of the weights (coefficients) of each of the components of overall satisfaction. Since they are measured in the same units (in a scale of 1 to 10), the coefficients and their standard errors can be compared directly.

The equation is estimated by OLS. Then we detect 29 outliers, corresponding to residuals that are larger than 3 standard deviations, and treat them using one dummy variable for each of them. Next, we use White's tests for heteroskedasticity. Upon detecting heteroskedasticity, we re-estimate the covariance matrix of the estimated

\footnotetext{
${ }^{1}$ See Anderson and Fornell (2000) for an excellent discussion of cardinality versus ordinality in this context. Note that the cardinality assumption is implicit whenever averages and standard deviations of (possibly ordinal) indexes are computed, even by some researchers that insist on the ordinal nature of satisfaction indices, e.g. Peel et al. (1998), page 81.
} 
coefficients using the Eicker-White (Eicker (1967) and White (1980) heteroskedasticity consistent covariance matrix estimator.

In Table 2 we observe first that all coefficients of the satisfaction indices are positive and significant and that the most important components are those of customer care $0.145(6.51)^{2}$, communications quality $0.136(4.74)$ and complementary services ${ }^{3} 0.124$ (4.90), followed by adequacy of rates 0.099 (4.24), cost 0.085 (4.77), easily acquire new handsets 0.068 (3.21), coverage 0.067 (3.08), and bill clarity 0.067 (2.80), while easily finding rates and offers 0.02 (0.81) is insignificant. This is shown in Figure 5.

\section{[Figure 5 goes here]}

We also observe in Table 2 that the operator dummies are insignificant, as can be expected, since the operator effect should be already embedded in each of the components of satisfaction. Also, the dummies for Autonomous Communities are jointly significant: they are used to control the heterogeneity that may be present due to the peculiarities of each specific autonomous community.

3.b. Models M1 to M10. Aspects of satisfaction.

After analyzing the components of overall satisfaction, we proceed to the quantification of the variables that influence the value of each component together with those that determine overall satisfaction, contained in Table 3.

Table 3 considers two groups of determinants of the satisfaction with each aspect.

a. The factors that are influential in the satisfaction of the individual customers with respect to the mobile carriers by their customers. We are referring to a set of dummy variables such as geographical location, age, gender, education, and expenditure, etc.

b. The valuations of each of the operators by their customers, that is, the operator effect.

\section{[Table 3 goes here]}

\footnotetext{
${ }^{2}$ t-statistics in parenthesis. Roughly, values above 2 are significant at the $2 \%$ and one side.

${ }^{3}$ Complementary services are free (voice mail, balance and customer care) or paying (sms, mms, downloads, mobile internet and information alerts).
} 
Table 3 contains the estimation of the different models for the components of satisfaction with different aspects of mobile telephony. The first row indicates that it's the model in which we control for Autonomous Communities, using a dummy for each one of them (minus one). Then columns M1 through M10 correspond to the ten different models. The dependent variable for each is in the second row of the table, starting with overall satisfaction, satisfaction with cost, satisfaction with the quality of communications, satisfaction with customer care, satisfaction with bill clarity, satisfaction with adequacy of rates, satisfaction with coverage, satisfaction with finding rates and offers easily, satisfaction with acquiring new handsets easily, and satisfaction with complementary services.

The first column contains the names of the different explanatory variables, which start with the carriers: Movistar, Vodafone, Orange, and VMO (we use Yoigo as a basis for comparison). These are followed by the rest of the socio-economic explanatory variables that have turned out to be significant in at least one of the models. And finally, the selected summary statistics such as the F test of joint significance, the White test for heteroskedasticity, coefficient of determination, and the number of observations.

\section{3.b.1. Model M1. Overall satisfaction and its explanatory variables.}

Starting with column M1 in Table 3, we find that the dependent variable is the overall satisfaction, and then we find the estimated coefficient for Movistar which is -0.42 , while the t-statistic -1.81 is below the estimated coefficient, which is significant at $5 \%$ and one side. The interpretation of the coefficient is that, after controlling for all the explanatory variables, being a customer of Movistar makes you essentially 0.42 unhappier on a scale of 1 to 10 .

A similar interpretation applies to the coefficients of Vodafone, $-0.34(-1.43)$ points less satisfied than a customer of Yoigo, and to the customers of Orange, which are -0.46 (1.92) points less satisfied than with Yoigo. Only the customers of virtual mobile operators are roughly equally satisfied as those of Yoigo, since the estimated coefficient is only $-0.024(-0.07)$ and insignificant.

The next block of explanatory variables in the model of overall satisfaction, M1, of Table 3 is: minimum monthly consumption, which is insignificant, and if a customer has contracted mobile internet, with which he/she tends to be more satisfied by 0.52 
(4.03) points. Spaniards tend to be less satisfied than foreign nationals by $-0.29(-3.37)$ points and males tend to be less satisfied than females by $-0.13(-2.49)$ points.

The next block of explanatory variables in the model of overall satisfaction, M1, is related to the various complaints that a customer may have filed in the last 12 months. The variables are dummies that take the value of 1 if at least one specific complaint has been filed and 0 if otherwise.

We can see that the overall satisfaction is significantly and negatively affected by coverage problems $-0.50(-6.91)^{4}$, incorrect billing $-0.40(-2.63)$, incorrect billing for services not used $-0.37(-2.34)$, and difficulty in obtaining the required information $0.72(-5.37)$. We observe that each of the estimates indicates large effect on overall satisfaction of the complaints by the customers.

We also use a constant together with 16 dummies to control for heterogeneity across autonomous communities. We then show the number of individual dummies that we used in each model to treat the outliers (with residuals larger than 3 standard errors).

At the bottom of the column we show the number of observations, 3,311 [A1], the coefficient of determination, 0.262, the F test of joint significance, 101.38 which is highly significant, followed by a significant White test of heteroskedasticity. We consistently estimate the variance covariance matrix of the estimated coefficients using the Eicker-White (White (1980)) estimator.

\section{3.b.2. Models M2-M10. Satisfaction with specific items.}

Models M2 to M10 are specified and estimated using similar techniques to those of model M1. In the rest of Table 3, rows 3 to 7, the differences between the operators are interpreted as follows:

1. The difference in satisfaction with respect to cost (M2) is significant for all carriers. All the differences are negative and significant, with the largest one for Movistar with respect to Yoigo, which is $-2.06(-8.39)$ points.

2. The differences in satisfaction with respect to communications quality (M3) are small and insignificant.

\footnotetext{
${ }^{4}$ The first number represents points of satisfaction in a scale of 1 to10.
} 
3. The differences (with respect to Yoigo) in satisfaction with customer care (M4) are negative and significant for the three major carriers, with the largest one pertaining to Movistar with an estimate of -0.88 (-4.28) points.

4. The differences (with respect to Yoigo) in satisfaction with respect to clarity bill (M5) are negative and significant for the major carriers, being the largest one for Movistar with an estimate of -0.94 (-3.59) points.

5. The differences (with respect to Yoigo) in satisfaction due to rates (M6) are negative, the largest being Movistar with an estimate of $-1.41(-6.01)$ points.

6. The pattern of the differences in satisfaction due to coverage (M7) changes significantly with respect to the previous ones. The only negative differences are those of Orange with $-0.52(-2.14)$ points below Yoigo. On the other hand, the satisfaction with the coverage of Movistar has a positive, although insignificant value.

7. When it comes to the issue of easily finding rates and offers (M8), all major carriers have negative and significant differences with Yoigo, the largest being for Movistar with -0.89 (-3.94) points.

8. The difference in satisfaction with respect to easily acquiring new handsets (M9) is also negative for all carriers, the largest and most significant being for Movistar with an estimate of -0.75 (-1.97).

9. The satisfaction with respect to complementary services (M10) also shows insignificant differences between carriers.

Summarizing, if we control for the effect of other relevant variables, Movistar is the carrier that gives less satisfaction to its customers, except possibly in communications quality, coverage, and complementary services. This agrees with the simple averages of satisfactions shown in Figure 6.

\section{[Figure 6 goes here]}

The next least satisfying carriers are Vodafone and Orange, which come very close in most aspects of consumer satisfaction, except for Orange's significantly worse coverage. 
We have also performed similar estimations controlling for the 50 different provinces instead of the 17 Autonomous Communities. They are available from the authors upon request. We observe very similar coefficients to those in Table 3. We test the hypothesis that the coefficients are equal against the alternative that they are different. F tests of homogeneity of coefficients do not reject the null hypothesis of equality of coefficients at the 0.05 level of significance. We therefore base our inference on Table 3, which controls for Autonomous Communities, includes fewer parameters, and allows for more efficient estimation than the models that include dummies for the 50 provinces.

\section{Satisfaction with specific aspects of mobile telephony and customer complaints.}

Next let's consider in Table 3 the block of variables related to the complaints filed by individual customers. We now focus on columns M2 to M10 and on the rows corresponding to the 7 variables: delay in establishing the service, coverage problems, incorrect billing, incorrect billing for services not used, breach of contract or commercial offer, difficulty in cancelling the service, and difficulty in obtaining the required information.

The general conclusions that can be drawn from the estimation of the rest of Table 3 can be summarized as follows:

1. With respect to satisfaction with cost, the relevant variables are: having filed at least one complaint for coverage problems -0.45 (-4.77), difficulty in terminating the service $-0.69(-2.61)$, and difficulty in obtaining the required information $-0.78(-4.64)$. Note that the estimates of the coefficients are large when measured on a scale of 1 to 10 , and also in relation to the average satisfaction with respect to cost, which is 5.62 .

2. With respect to satisfaction with communications quality, all the estimated coefficients of the complaints are negative, as expected, they have relatively high coefficients and the most significant ones are: delay in establishment of service -0.53 (-2.09), coverage problems -0.98 (-13.33), and difficulty in obtaining the required information $-0.34(-2.48)$. All of them are large and significant. 
3. In a more general view of Table 3 , we observe that coverage problems are always relevant and have negative effects on all measures of satisfaction.

4. The next most important source of dissatisfaction is the difficulty in obtaining the required information, which is significant in all but one of the models.

5. Next comes the breach of contract or commercial offer, which has a negative and significant effect on four measures of satisfaction.

\section{Conclusions}

The focus of this paper is to analyze customer satisfaction among private individual consumers of mobile telecommunications in Spain and the factors associated with it. We use data on 4,953 individual consumers from the survey: "Satisfacción de Usuarios de servicios de telecomunicación”, conducted by the Centro de Investigaciones Sociológicas (CIS), Spain. Our data include place of residence (Autonomous Regions and province), gender, age, educational level, and other socioeconomic and technical variables. We formulate and estimate regression models for different aspects of satisfaction and its possible determinants.

The main conclusions are as follows:

- We find that each component of overall satisfaction has a positive and significant effect, and the most important items are, in this order, customer care, communications quality and complementary services, followed by adequacy of rates, cost, easily acquire new handsets, bill clarity and coverage, while the least important is easily finding rates and offers which is insignificant. Then, service providers should consider the importance that consumers attach to after sles care and make a special effort to invest in that area.

- Next, we model the determinants of overall satisfaction. After controlling for all the explanatory variables, our results indicate that customers are less satisfied with larger well established carriers, like Movistar and Vodafone, and more satisfied with smaller and newer operators. 
- When considering satisfaction with other attributes, we find that Movistar is the carrier that gives less satisfaction to its customers, except in communications quality, coverage, and complementary services.

- Spaniards tend to be less satisfied than foreign nationals and males tend to be less satisfied than females.

- We also find that overall satisfaction is significantly and negatively affected by complaints about coverage problems, incorrect billing, incorrect billing for services not used, and difficulty in obtaining the required information.

- With respect to satisfaction with cost, the relevant variables are: having filed at least one complaint for coverage problems, difficulty in terminating the service, and difficulty in obtaining the required information. Note that the estimates of the coefficients are large when measured on a scale from 1 to 10 .

- With respect to satisfaction with communications quality, as expected, all the estimated coefficients of the complaints are negative. They have relatively large coefficients and the most significant ones are: delay in establishment of service, coverage problems, and difficulty in obtaining the required information.

- In general, we observe that complaints about coverage problems are always relevant and have a negative effect on all measures of satisfaction.

- The next most important source of dissatisfaction is the difficulty in obtaining the required information, which is significant in all but one of the models.

- The breach of contract or commercial offer, appears to have a negative and significant effect on four measures of satisfaction.

Summarizing, we have found significant and sizeable effects of many different variables on satisfaction, suggesting that if they could be manipulated by the operators and/or the regulators they could substantially enhance consumer satisfaction.

It's likely that the reason why some carriers have been steadily losing market share is because of unsatisfied customers and not just because of competition. Operators should look at their own performance and customer satisfaction and try to work on the variables that influence satisfaction and lie within their control. 
If we focus on point 4 of these conclusions we realize that a successful effort to reduce complaints about billing and difficulty for obtaining the required information can result in a substantial improvement in satisfaction of up to 1.5 points. This is probably a cost effective policy by operators ${ }^{5}$. For instance, Movistar's recent move of transferring its call center from Colombia back to Spain could a step in the right direction.

A possible policy recommendation for regulators is to watch those variables with higher coefficients that are more manipulable and decide whether certain regulations may be appropriate to increase consumer welfare. The Ministry of Industry's initiative to set up a web page and call center (http://usuariosteleco.es/) to mediate disputes between customers and operators may also be a step in the right direction. Though more publicity of this service may be needed.

The 2009 data may seem somewhat outdated, it must be noted first that the purpose of this paper is to study relationships that are expected to be stable over time, and second that the project is currently developing a new survey on the satisfaction of mobile consumers to be launched next year, and the study with 2009 data will be a useful point of comparison for the new 2013 study.

While the results are specific to Spain, it would be very interesting to analyze data for other countries, since it's possible that similar results hold elsewhere.

\footnotetext{
${ }^{5}$ Although we recognize that coverage problems may be costly to solve, handling complaints about coverage efficiently will always improve consumer satisfaction.
} 


\section{References}

Álvarez, O. and F. Caballero (1995), Liberalización del mercado europeo de servicios de telecomunicaciones: evaluación de la adaptación de España al nuevo entorno competitivo. Papeles de Economía Española, 63, 252-268. ISSN 0210-9107.

Anderson, E. W. and C. Fornell (2000), Foundations of the American Customer Satisfaction Index. Total Quality Management, 11, 7, 869-882. ISSN 0954-4127 Taylor \& Francis Ltd.

CIS, Centro de Investigaciones Sociológicas (2009) Satisfacción de Usuarios de Servicios de Telecomunicación. Estudio 2797, March - April.

Davies, J., Howell, B. and V. Mabin (2008), Telecommunications Regulation, Regulatory Behavior and its Impact - A Systems View. Communications \& Strategies, 70, 145-167.

Dedrick, J., Kraemer, K.L. and G. Linden (2011), The distribution of value in the mobile phone supply chain. Telecommunications Policy, 35, 6, 505-521.

Diehl, K.A. (2010), Telecommunications companies: One meeting with any competitor is enough to violate the EU's competition laws and result in fines. Telecommunications Policy, 34, 4, 248-250.

Eicker, F. (1967), Limit Theorems for Regressions with Unequal and Dependent Errors, Proceedings of the Fifth Berkeley Symposium on Mathematical Statistics and Probability 1, 59-82. Berkeley: University of California Press

García Zaballos, A. and A. Escribano (2002), Evolución de la estructura de mercado de las telecomunicaciones en España. Economistas, 20, 91, 336-344. ISSN 0212-4386

Garín-Muñoz, T., Pérez Amaral, T., C. Gijón and R. López (2012), Customer Satisfaction of Mobile Internet users: An empirical approximation to the case of Spain. Universidad Complutense de Madrid. Mimeo.

González, P., García Zaballos, A. and A. Escribano (2003), Análisis económico de las telecomunicaciones en España: fortalezas y debilidades. Información Comercial Española, ICE: Revista de economía, 808, 71-103. ISSN 0019-977X.

Hardie, N. and P. Walsh (1994) Towarsd a better understanding of quality. International Journal of Quality \&Reliability Management, 11, 53-63.

Herguera, I. (2001), Un análisis de la situación del sector de las telecomunicaciones en España: aspectos regulatorios y de competencia. Ekonomiaz: Revista vasca de economía, 46, 154-181. ISSN 0213-3865.

Jarillo, J.C. (1995), Empresas multinacionales y telecomunicaciones. Economía Industrial, 303, 121-127. ISSN 0422-2784.

Karacuka, M., Haucap, J. and U. Heimeshoff (2011), Competition in Turkish mobile telecommunications markets: Price elasticities and network substitution. Telecommunications Policy, 35, 2, 202-210.

Ladhari, R. (2009) A review of twenty years of SERVQUAL research. International Journal of Quality and Service Sciences, 1(2), 172-198.

Lam, P-L. and A. Shiu (2010), Economic growth, telecommunications development and productivity growth of the telecommunications sector: Evidence around the world. Telecommunications Policy, 34, 4, 185-199.

Lee, Y.-C. (2011), Competitive relationships between traditional and contemporary telecommunication services in Taiwan. Telecommunications Policy, 35, 543-554.

Lescop, D. and T. Isckia (2010), (Re)shaping the Mobile Sector: the Breaker, the Trojan and... the Shopping Malls. Communications \& Strategies, 78, 161-169.

López, R., Pérez Amaral, T., Garín-Muñoz, T. and C. Gijón (2012), Service quality and asymmetric information in mobile telecommunications: a game theoretical approach to consumer protection. Universidad Complutense de Madrid. Mimeo.

Ono, S. and P. Tang (2010), The role of mobile handsets in advanced network service evolution: Evidence from Japan. Telecommunications Policy, 34, 8, 444-460. 
Osa, J. (2001), El futuro en la regulación de las telecomunicaciones Unión Europea y España. Economía Industrial, 337, 67-74.

Palcic, D. and E. Reeves (2010), Organizational status change and performance: The case of Ireland's national communications operator. Telecommunications Policy, 34, 56, 299-308.

Papke, L. E. (1998), How are participants investing their accounts in participant-directed individual account pension plans? American Economic Review, 88, 212-216.

Parasuraman, A., Zeithaml, V.A., and Berry, L.L. (1985) A conceptual model of service quality and its implications for future research. Journal of Marketing. 49, 41-50.

Peel, M.J., Goode, M.M.H. and L.A. Moutinho (1998), Estimating consumer satisfaction: OLS versus Ordered Probability Models, International Journal of Commerce \& Management, 8, 2, 75-93.

Renda, A. (2010), Competition-regulation interface in telecommunications: What's left of the essential facility doctrine. Telecommunications Policy, 34, 1-2, 23-35.

Song, J-D. (2010), Various wholesale price equilibria for mobile virtual network operators. Telecommunications Policy, 34, 10, 633-648.

Soto, J., Pérez, J. and C. Feijóo (2003), Veinticinco años de la sociedad de la información en España: evolución tecnológica, globalización y políticas públicas. Economía Industrial, 349-350, 63-82. ISSN 0422-2784.

Symeou, P.C. (2011), Economy size and performance: An efficiency analysis in the telecommunications sector. Telecommunications Policy, 35, 5, 426-440.

White, H. (1980), A Heteroskedasticity-Consistent Covariance Matrix Estimator and a Direct Test for Heteroskedasticity, Econometrica 48, 817-838.

Wooldridge, J. (2010), Econometric Analysis of Cross Section and Panel Data, $2^{\text {nd }}$ Edition, MIT Press, Cambridge, Massachusetts.

Zhang, J. and X.-J. Liang (2011), Business ecosystem strategies of mobile network operators in the $3 \mathrm{G}$ era: The case of China Mobile. Telecommunications Policy, $35,2,156-171$.

\section{Additional References}

- Australia Communications and Media Authority, ACMA. http://www.acma.gov.au/

- Centro de Investigaciones Sociológicas, CIS (2009) "Satisfacción de Usuarios de servicios de telecomunicación". http://www.cis.es

- Comisión del Mercado de las Telecomunicaciones. http://www.cmt.es/

- El País (2012) http://sociedad.elpais.com/sociedad/2012/08/23/actualidad/1345746537 436783.ht $\underline{\mathrm{ml}}$

- FACUA, Federación de asociaciones de consumidores. http://www.facua.org/

- Governor's Office of Consumer protection, Georgia, http://consumer.georgia.gov/consumer-topics/cell-phones

- Improving Consumer Protection in Cell Phone / Wireless Device Contracts Public Consultation Paper December 2010, Manitoba Consumer Protection Office, Canada. http://www.gov.mb.ca/fs/cca/cpo/pubs/cellphone.pdf

- Ministerio de Industria, Oficina de atención al usuario de telecomunicaciones. http://www.usuariosteleco.es/

- Ministerio de Industria, (2012) http://www.minetur.gob.es/telecomunicaciones/esES/Servicios/CalidadServicio/1PublicacionNivelesCalidad/Paginas/calidades.aspx 
Figure 1. Mobile operators by market share

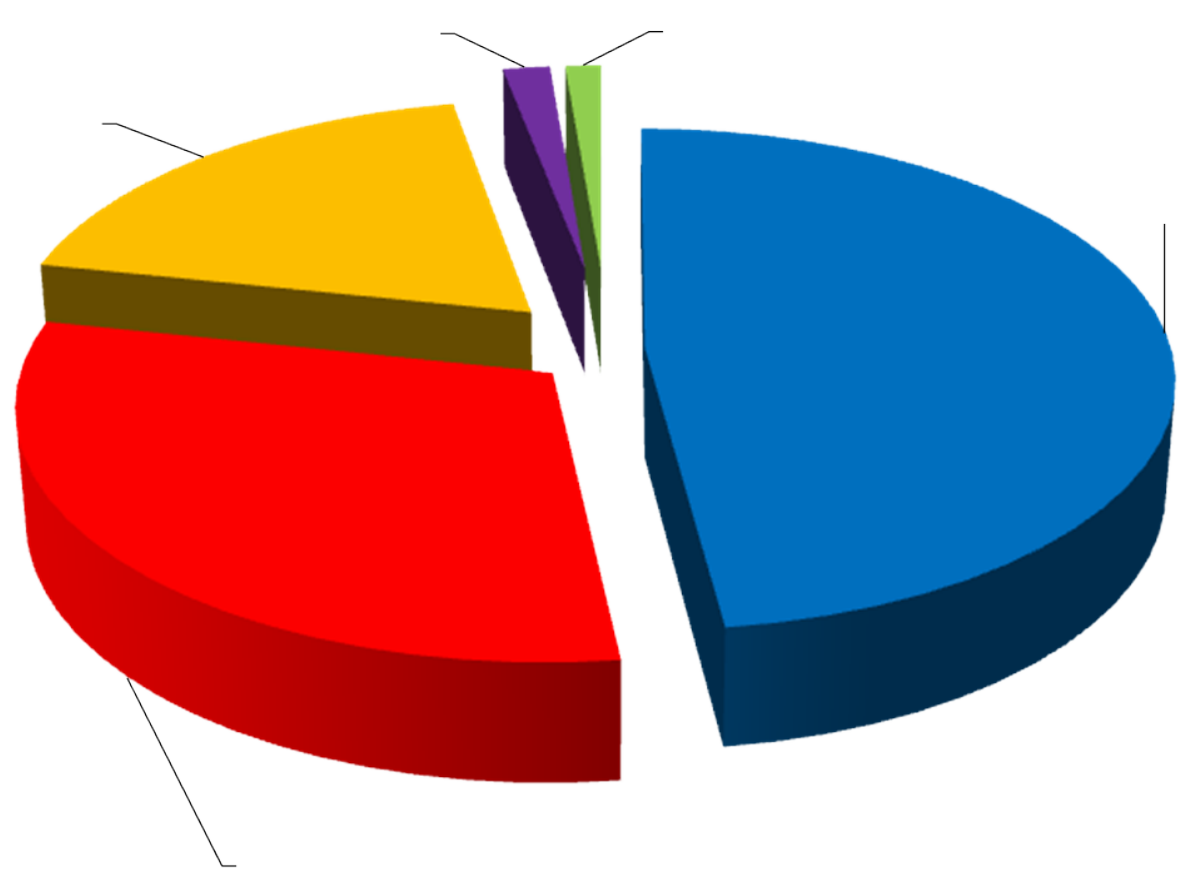


Figure 2. Satisfaction with specific aspects of mobile telephone services.
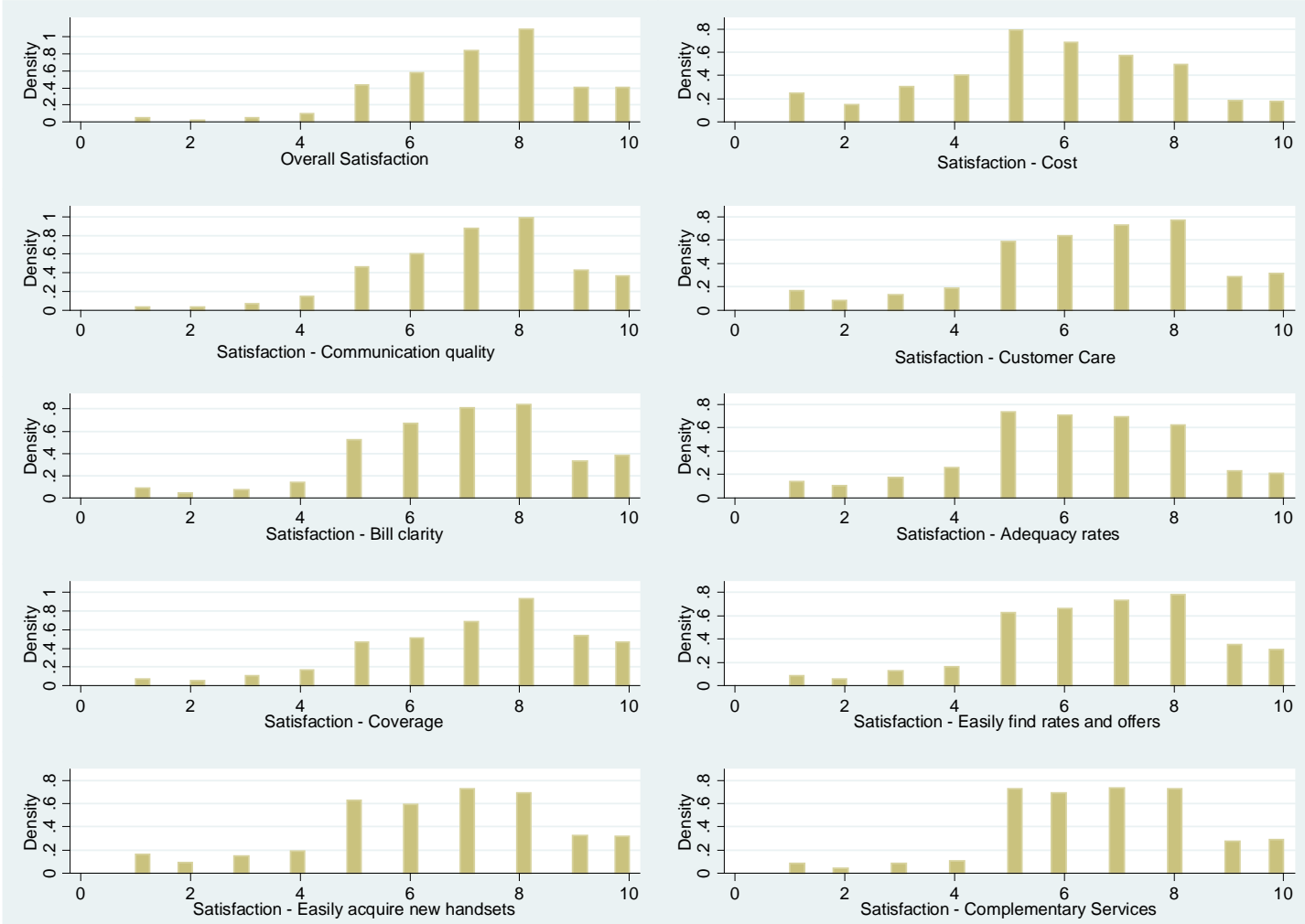
Figure 3. Overall satisfaction vs possible determinants
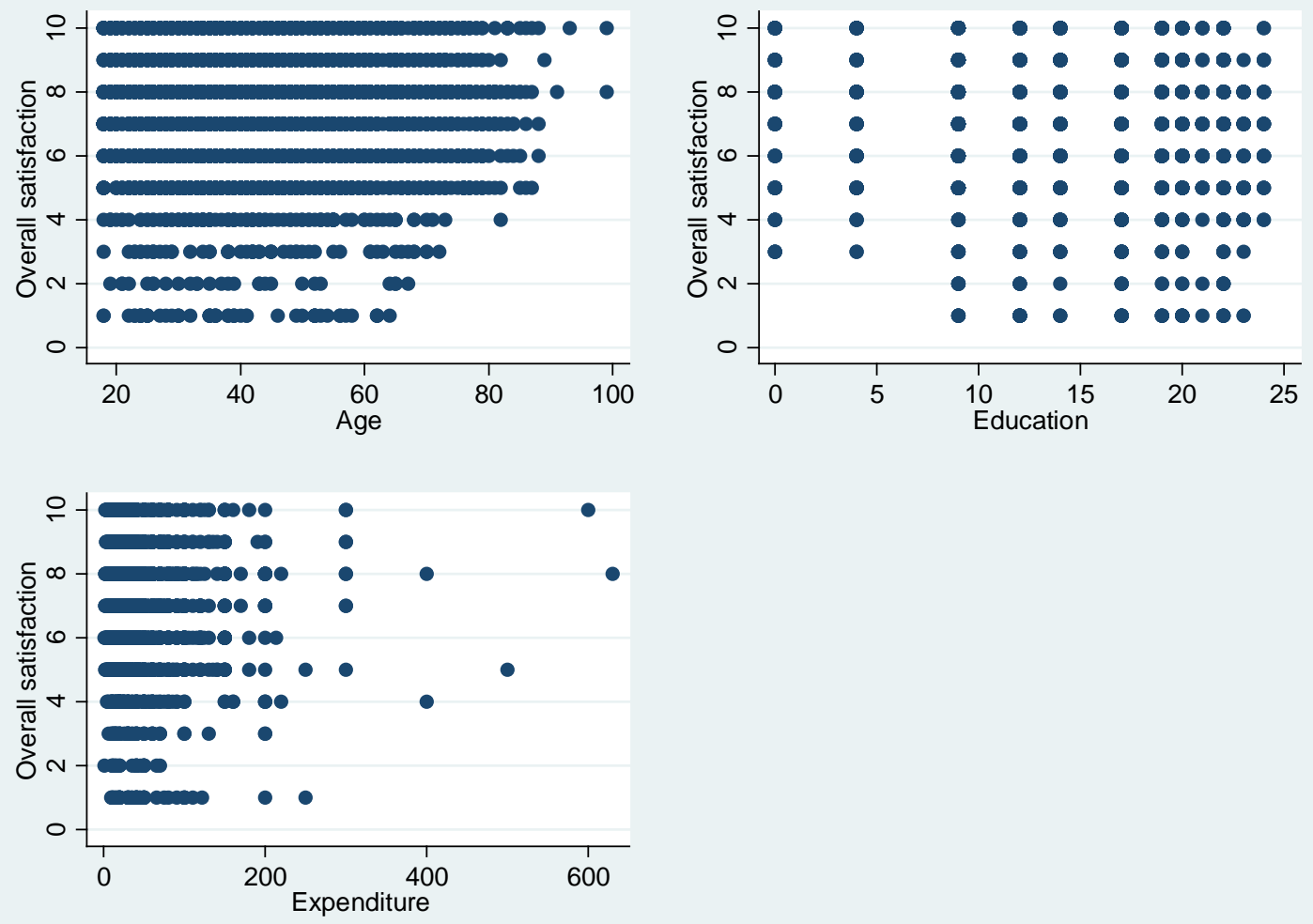
Figure 4. Averages of Satisfaction by its characteristics

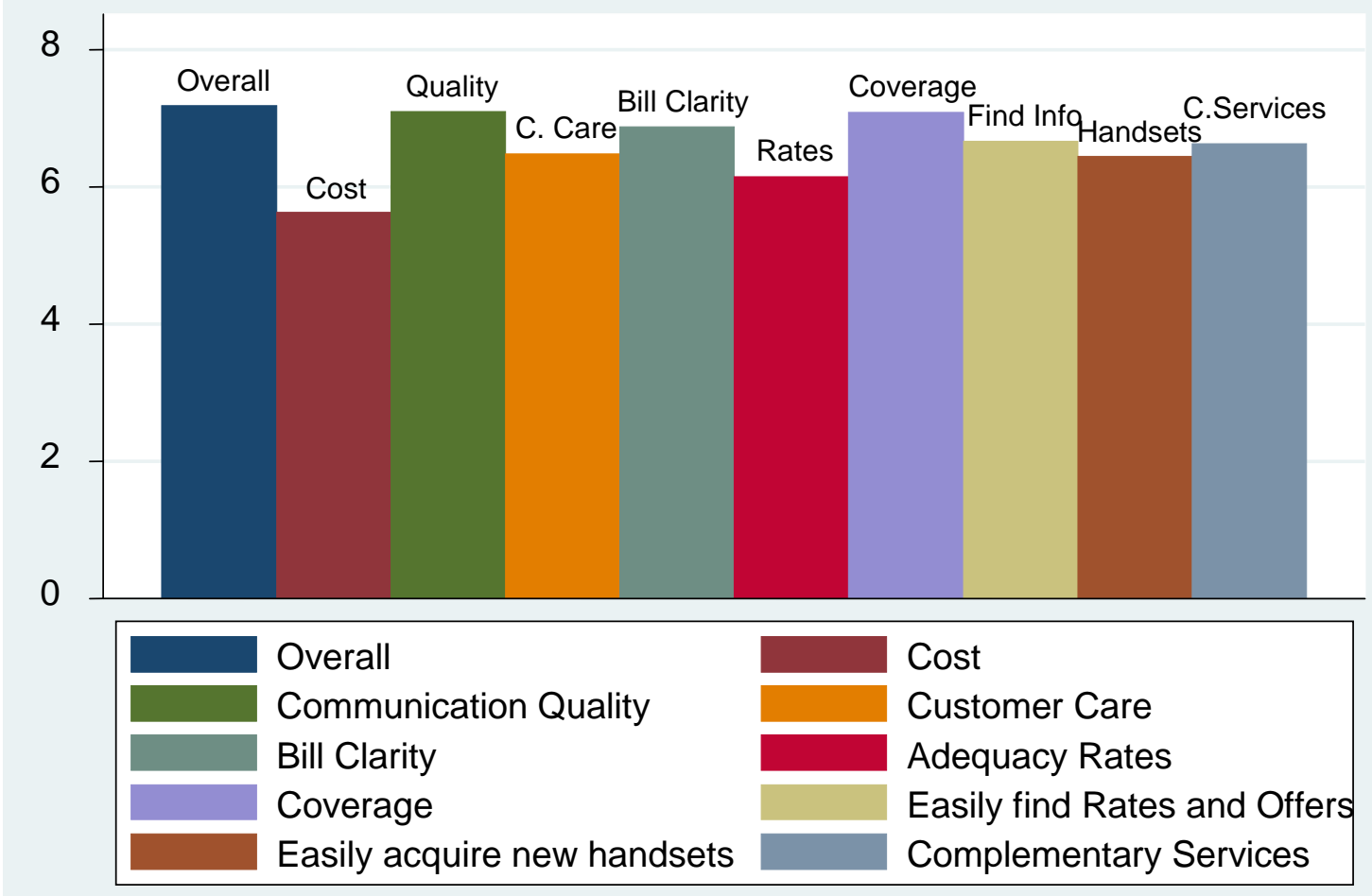


Figure 5. Overall satisfaction: weights of its components

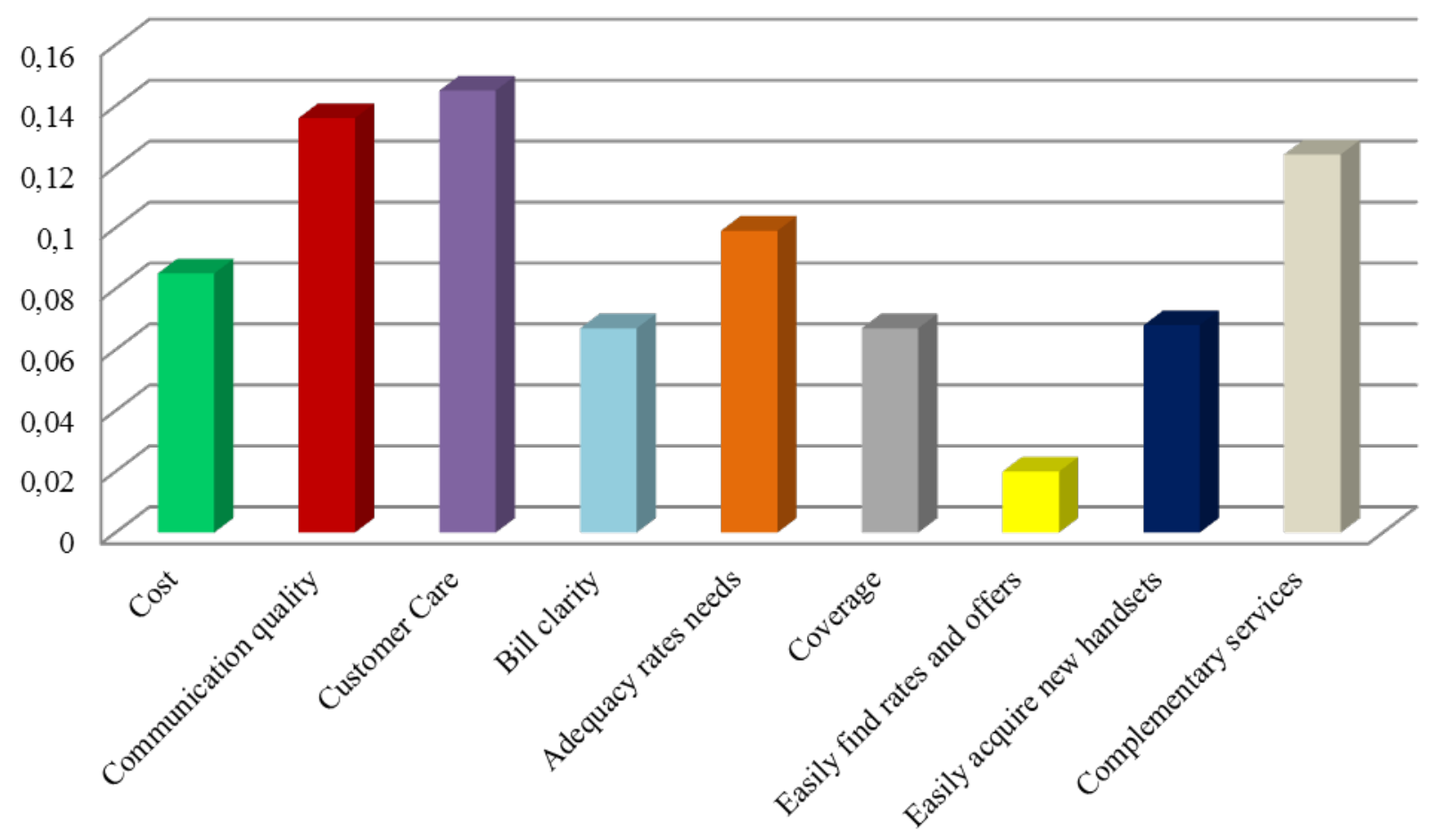


Figure 6. Mean of overall satisfaction by operator.

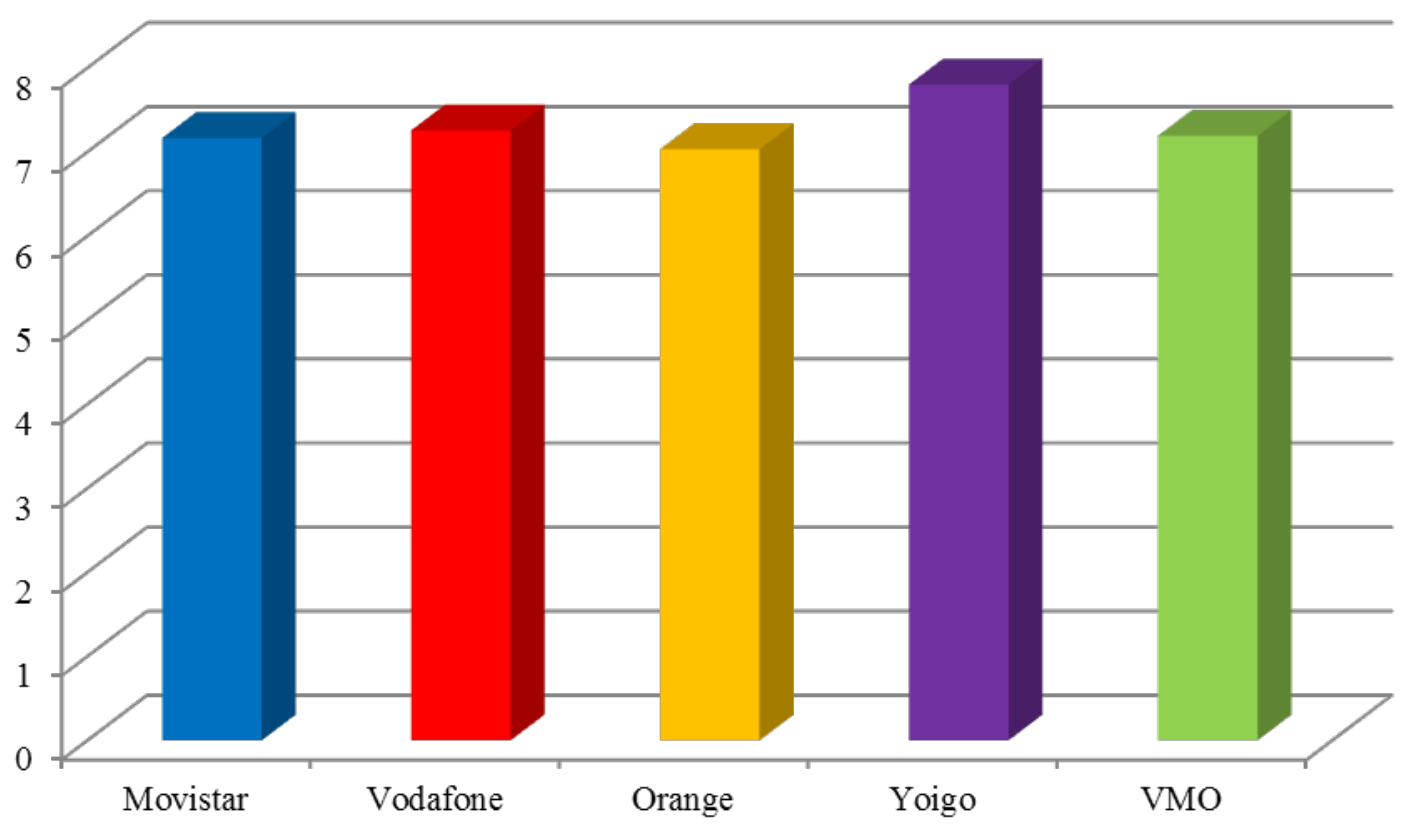


Table 1. Descriptive statistics of selected variables

\begin{tabular}{lccccc}
\hline \multicolumn{1}{c}{ Variable } & Obs. & Average & Std. Dev. & Min & Max \\
Satisfaction overall & 4177 & 7.18 & 1.79 & 1 & 10 \\
Satisfaction Cost & 4045 & 5.62 & 2.25 & 1 & 10 \\
Satisfaction Communication quality & 4130 & 7.09 & 1.78 & 1 & 10 \\
Satisfaction Customer Care & 3555 & 6.48 & 2.18 & 1 & 10 \\
Satisfaction Bill clarity & 3223 & 6.88 & 1.95 & 1 & 10 \\
Satisfaction Adequacy of rates & 3605 & 6.15 & 2.10 & 1 & 10 \\
Satisfaction Coverage & 4121 & 7.09 & 2.05 & 1 & 10 \\
Satisfaction easily find rates and offers & 3513 & 6.67 & 2.01 & 1 & 10 \\
Satisfaction easily acquire new handsets & 3524 & 6.44 & 2.22 & 1 & 10 \\
Satisfaction Complementary Services & 2907 & 6.63 & 1.94 & 1 & 10 \\
\hline
\end{tabular}

\begin{tabular}{lccccc}
\hline \multicolumn{1}{c}{ Variable } & Obs & Average & Std. Dev. & Min & Max \\
Broadband mobile Internet & 4233 & .04 & .21 & 0 & 1 \\
Expenditure & 4562 & 30.72 & 37.51 & 0 & 630 \\
Education & 4936 & 13.45 & 5.74 & 0 & 24 \\
Male & 4953 & .49 & .50 & 0 & 1 \\
Age & 4953 & 46.79 & 17.94 & 18 & 99 \\
\hline
\end{tabular}

\begin{tabular}{|c|c|c|c|c|c|}
\hline Carrier & Obs. & Average & Std. Dev. & Min & Max \\
\hline Movistar & 4206 & .48 & .50 & 0 & 1 \\
\hline Vodafone & 4206 & .30 & .46 & 0 & 1 \\
\hline Orange & 4206 & .19 & .39 & 0 & 1 \\
\hline Virtual Mobile Operators & 4206 & .01 & .11 & 0 & 1 \\
\hline Yoigo & 4206 & .02 & .13 & 0 & 1 \\
\hline
\end{tabular}


Table 2. Overall satisfaction and its determinants

\begin{tabular}{|c|c|}
\hline & M0 \\
\hline Dependent variable: & Overall Satisfaction \\
\hline Movistar & $\begin{array}{l}-.050 \\
(-0.21)\end{array}$ \\
\hline Vodafone & $\begin{array}{c}.015 \\
(0.06)\end{array}$ \\
\hline Orange & $\begin{array}{c}-.049 \\
(-0.20)\end{array}$ \\
\hline VMO & $\begin{array}{c}.007 \\
(0.02)\end{array}$ \\
\hline $\begin{array}{l}\text { Satisfaction } \\
\text { Cost }\end{array}$ & $\begin{array}{c}.085 \\
(4.77)\end{array}$ \\
\hline $\begin{array}{c}\text { Satisfaction } \\
\text { Communication quality }\end{array}$ & $\begin{array}{c}.136 \\
(4.74)\end{array}$ \\
\hline Satisfaction Customer Care & $\begin{array}{c}.145 \\
(6.51)\end{array}$ \\
\hline $\begin{array}{l}\text { Satisfaction } \\
\text { Bill clarity }\end{array}$ & $\begin{array}{c}.067 \\
(2.80)\end{array}$ \\
\hline $\begin{array}{c}\text { Satisfaction } \\
\text { Adequacy of rates }\end{array}$ & $\begin{array}{c}.099 \\
(4.24)\end{array}$ \\
\hline $\begin{array}{l}\text { Satisfaction } \\
\text { Coverage }\end{array}$ & $\begin{array}{c}.067 \\
(3.08)\end{array}$ \\
\hline $\begin{array}{c}\text { Satisfaction } \\
\text { Easily find rates and offers }\end{array}$ & $\begin{array}{c}.02 \\
(0.81)\end{array}$ \\
\hline $\begin{array}{c}\text { Satisfaction } \\
\text { Easily acquire new handsets }\end{array}$ & $\begin{array}{c}.068 \\
(3.21)\end{array}$ \\
\hline $\begin{array}{c}\text { Satisfaction } \\
\text { Complementary Services }\end{array}$ & $\begin{array}{c}.124 \\
(4.90)\end{array}$ \\
\hline $\begin{array}{l}\text { +16 dummies for A.C. } \\
\text { F (p-value) }\end{array}$ & $\begin{array}{c}F(16,2174)=2.90 \\
(0.0001)\end{array}$ \\
\hline Constant & $\begin{array}{l}1.844 \\
(6.22)\end{array}$ \\
\hline Number of outliers & 29 \\
\hline $\begin{array}{c}\text { F (joint signif. coefficients) } \\
\text { (p-value) }\end{array}$ & $\begin{array}{c}104.94 \\
(0.0000)\end{array}$ \\
\hline $\begin{array}{c}\text { White test, } \chi^{2} \\
\text { (p-value) }\end{array}$ & $\begin{array}{c}278.62 \\
(0.0000)\end{array}$ \\
\hline Degrees of freedom White & 32 \\
\hline $\mathrm{R}^{2}$ & 0.5757 \\
\hline $\mathrm{n}$ & 2206 \\
\hline
\end{tabular}

Notes: In parenthesis t-statistics. We use heteroskedasticity consistent covariance matrix estimates (Eicker-White). 
Table 3. Equations of overall and specific items of individual customer satisfaction.

\begin{tabular}{|c|c|c|c|c|c|}
\hline & M1 & M2 & M3 & M4 & M5 \\
\hline Endogenous & $\begin{array}{c}\text { Overall } \\
\text { satisfaction }\end{array}$ & $\begin{array}{l}\text { Satisfaction } \\
\text { Cost }\end{array}$ & $\begin{array}{c}\text { Satisfaction } \\
\text { Communication } \\
\text { quality }\end{array}$ & $\begin{array}{c}\text { Satisfaction } \\
\text { Customer Care }\end{array}$ & $\begin{array}{l}\text { Satisfaction } \\
\text { Bill clarity }\end{array}$ \\
\hline Movistar & $\begin{array}{c}-.42 \\
(-1.81)\end{array}$ & $\begin{array}{c}-2.06 \\
(-8.39)\end{array}$ & $\begin{array}{c}-.24 \\
(-1.13)\end{array}$ & $\begin{array}{c}-88 \\
(-4.28)\end{array}$ & $\begin{array}{c}-.94 \\
(-3.59)\end{array}$ \\
\hline Vodafone & $\begin{array}{c}-34 \\
(-1.43)\end{array}$ & $\begin{array}{l}-1.74 \\
(-7.00)\end{array}$ & $\begin{array}{c}.20 \\
(-0.96)\end{array}$ & $\begin{array}{c}-58 \\
(-2.79)\end{array}$ & $\begin{array}{c}-.78 \\
(-2.95)\end{array}$ \\
\hline Orange & $\begin{array}{c}-.46 \\
(-1.92)\end{array}$ & $\begin{array}{l}-1.54 \\
(-6.08)\end{array}$ & $\begin{array}{c}-.32 \\
(-1.51)\end{array}$ & $\begin{array}{c}-.69 \\
(-3.27)\end{array}$ & $\begin{array}{c}-.80 \\
(-3.01)\end{array}$ \\
\hline VMO & $\begin{array}{l}-.024 \\
(-0.07)\end{array}$ & $\begin{array}{l}-1.01 \\
(-2.37)\end{array}$ & $\begin{array}{c}.09 \\
(-0.31)\end{array}$ & $\begin{array}{c}-34 \\
(-1.02)\end{array}$ & $\begin{array}{c}-46 \\
(-1.21)\end{array}$ \\
\hline $\begin{array}{c}\text { Cheaper calls at certain } \\
\text { times or days }\end{array}$ & & & & & $\begin{array}{c}-.26 \\
(-3.67)\end{array}$ \\
\hline $\begin{array}{l}\text { Minimum monthly } \\
\text { consumption }\end{array}$ & $\begin{array}{c}-.04 \\
(-0.79)\end{array}$ & $\begin{array}{c}.34 \\
(4.37)\end{array}$ & & & \\
\hline $\begin{array}{c}\text { Cheaper calls to } \\
\text { numbers chosen by you }\end{array}$ & & & & $\begin{array}{c}.18 \\
(2.66)\end{array}$ & $\begin{array}{c}.24 \\
(3.38)\end{array}$ \\
\hline $\begin{array}{l}\text { Has contracted mobile } \\
\text { broadband Internet }\end{array}$ & $\begin{array}{c}.52 \\
(4.03)\end{array}$ & & & & \\
\hline Expenditure & $\begin{array}{l}-.002 \\
(-1.77)\end{array}$ & $\begin{array}{l}-.012 \\
(-6.89)\end{array}$ & $\begin{array}{l}-.0008 \\
(-0.65)\end{array}$ & & $\begin{array}{l}.0019 \\
(2.10)\end{array}$ \\
\hline Expenditure sq & $\begin{array}{c}7.06 \mathrm{e}-06 \\
(2.08)\end{array}$ & $\begin{array}{l}.00003 \\
(4.96)\end{array}$ & $\begin{array}{c}2.39 \mathrm{e}-06 \\
(0.53)\end{array}$ & & \\
\hline Spaniard & $\begin{array}{c}-.29 \\
(-3.37)\end{array}$ & $\begin{array}{c}-.35 \\
(-2.90)\end{array}$ & $\begin{array}{c}-.32 \\
(-3.77)\end{array}$ & $\begin{array}{c}-.46 \\
(-4.31)\end{array}$ & \\
\hline Male & $\begin{array}{c}-.13 \\
(-2.49)\end{array}$ & & $\begin{array}{c}-.06 \\
(-1.18)\end{array}$ & & \\
\hline Age & & & & $\begin{array}{c}.008 \\
(3.18)\end{array}$ & \\
\hline $\begin{array}{l}\text { Delay in establishing } \\
\text { the service }\end{array}$ & $\begin{array}{c}-.24 \\
(-1.29)\end{array}$ & $\begin{array}{c}.15 \\
(0.49)\end{array}$ & $\begin{array}{c}-.53 \\
(-2.09)\end{array}$ & $\begin{array}{c}-.18 \\
(-0.72)\end{array}$ & $\begin{array}{c}-.64 \\
(-2.03)\end{array}$ \\
\hline Coverage Problems & $\begin{array}{c}-.50 \\
(-6.91)\end{array}$ & $\begin{array}{c}-45 \\
(-4.77)\end{array}$ & $\begin{array}{c}-.98 \\
(-13.33)\end{array}$ & $\begin{array}{c}-.47 \\
(-5.40)\end{array}$ & $\begin{array}{c}-.30 \\
(-3.29)\end{array}$ \\
\hline Incorrect billing & $\begin{array}{c}-.40 \\
(-2.63)\end{array}$ & $\begin{array}{c}-39 \\
(-1.82)\end{array}$ & $\begin{array}{c}-.19 \\
(-1.09)\end{array}$ & $\begin{array}{c}-58 \\
(-2.76)\end{array}$ & $\begin{array}{c}-.49 \\
(-2.22)\end{array}$ \\
\hline $\begin{array}{l}\text { Incorrect billing for } \\
\text { services not used }\end{array}$ & $\begin{array}{c}-37 \\
(-2.34)\end{array}$ & $\begin{array}{c}-.30 \\
(-1.41)\end{array}$ & $\begin{array}{c}-34 \\
(-1.99)\end{array}$ & $\begin{array}{c}-.52 \\
(-2.56)\end{array}$ & $\begin{array}{c}-.75 \\
(-3.69)\end{array}$ \\
\hline $\begin{array}{l}\text { Breach of contract or } \\
\text { commercial offer }\end{array}$ & $\begin{array}{c}-.23 \\
(-1.31)\end{array}$ & $\begin{array}{c}-.43 \\
(-1.80)\end{array}$ & $\begin{array}{c}-.16 \\
(-0.87)\end{array}$ & $\begin{array}{c}-.29 \\
(-1.29)\end{array}$ & $\begin{array}{c}.19 \\
(0.80)\end{array}$ \\
\hline $\begin{array}{l}\text { Difficulty in cancelling } \\
\text { the service }\end{array}$ & $\begin{array}{c}-.12 \\
(-0.64)\end{array}$ & $\begin{array}{c}-.69 \\
(-2.61)\end{array}$ & $\begin{array}{c}-.22 \\
(-1.20)\end{array}$ & $\begin{array}{c}-.47 \\
(-2.05)\end{array}$ & $\begin{array}{c}-.26 \\
(-1.02)\end{array}$ \\
\hline $\begin{array}{l}\text { Difficulty in obtaining } \\
\text { the required info. }\end{array}$ & $\begin{array}{c}-.72 \\
(-5.37)\end{array}$ & $\begin{array}{c}-78 \\
(-4.64)\end{array}$ & $\begin{array}{c}-34 \\
(-2.48)\end{array}$ & $\begin{array}{l}-1.54 \\
(-9.60)\end{array}$ & $\begin{array}{c}-.65 \\
(-4.20)\end{array}$ \\
\hline $\begin{array}{l}\text { +16 dummies for A.C. } \\
\text { F (p-value) }\end{array}$ & $\begin{array}{c}\mathrm{F}(16,3441)= \\
5.19 \\
(0.0000)\end{array}$ & $\begin{array}{c}\mathrm{F}(16,3409)= \\
4.26 \\
(0.0000)\end{array}$ & $\begin{array}{c}F(16,3704)= \\
6.26 \\
(0.0000)\end{array}$ & $\begin{array}{c}F(16,3256)= \\
11.03 \\
(0.0000)\end{array}$ & $\begin{array}{c}\mathrm{F}(16,2832)= \\
8.20 \\
(0.0000)\end{array}$ \\
\hline Constant & $\begin{array}{c}7.97 \\
(30.81)\end{array}$ & $\begin{array}{c}8.25 \\
(27.84)\end{array}$ & $\begin{array}{c}7.88 \\
(32.65)\end{array}$ & $\begin{array}{c}7.14 \\
(29.30)\end{array}$ & $\begin{array}{c}7.43 \\
(26.83)\end{array}$ \\
\hline Num. outliers & 55 & 2 & 38 & 70 & 31 \\
\hline $\begin{array}{c}\mathrm{F} \\
\text { (p-value) }\end{array}$ & $\begin{array}{c}101.38 \\
(0.0000)\end{array}$ & $\begin{array}{c}11.47 \\
(0.0000)\end{array}$ & $\begin{array}{c}124.27 \\
(0.0000)\end{array}$ & $\begin{array}{c}70.40 \\
(0.0000)\end{array}$ & $\begin{array}{c}49.85 \\
(0.0000)\end{array}$ \\
\hline White test, $\chi^{2}$ & 64.91 & 63.10 & 81.04 & 158.86 & 81.82 \\
\hline $\mathrm{R}^{2}$ & 0.2624 & 0.1072 & 0.2119 & 0.2812 & 0.1969 \\
\hline $\mathrm{n}$ & 3311 & 3285 & 3552 & 3139 & 2620 \\
\hline
\end{tabular}

Notes: Using heteroskedasticity consistent covariance matrix estimates (Eicker-White) 
Table 3. Continued.

\begin{tabular}{|c|c|c|c|c|c|}
\hline & M6 & M7 & M8 & M9 & M10 \\
\hline Endogenous & $\begin{array}{c}\text { Satisfaction } \\
\text { adequacy rates }\end{array}$ & $\begin{array}{l}\text { Satisfaction } \\
\text { coverage }\end{array}$ & $\begin{array}{l}\text { Satisfaction } \\
\text { easily find rates } \\
\text { and offers }\end{array}$ & $\begin{array}{c}\text { Satisfaction } \\
\text { easily acquire } \\
\text { new handsets }\end{array}$ & $\begin{array}{c}\text { Satisfaction } \\
\text { complementary } \\
\text { services }\end{array}$ \\
\hline Movistar & $\begin{array}{l}-1.41 \\
(-6.01)\end{array}$ & $\begin{array}{c}.11 \\
(0.44)\end{array}$ & $\begin{array}{c}.89 \\
(-3.94)\end{array}$ & $\begin{array}{c}-.75 \\
(-1.97)\end{array}$ & $\begin{array}{c}-.43 \\
(-1.56)\end{array}$ \\
\hline Vodafone & $\begin{array}{l}-1.16 \\
(-4.89)\end{array}$ & $\begin{array}{c}-.22 \\
(-0.91)\end{array}$ & $\begin{array}{c}-.58 \\
(-2.56)\end{array}$ & $\begin{array}{c}-.39 \\
(-1.02)\end{array}$ & $\begin{array}{c}-.31 \\
(-1.11)\end{array}$ \\
\hline Orange & $\begin{array}{l}-1.08 \\
(-4.50)\end{array}$ & $\begin{array}{c}-.52 \\
(-2.14)\end{array}$ & $\begin{array}{c}-.69 \\
(-2.99)\end{array}$ & $\begin{array}{c}-.46 \\
(-1.18)\end{array}$ & $\begin{array}{c}-.42 \\
(-1.49)\end{array}$ \\
\hline VMO & $\begin{array}{c}-.81 \\
(-1.84) \\
\end{array}$ & $\begin{array}{c}-.30 \\
(-0.84)\end{array}$ & $\begin{array}{c}-.71 \\
(-1.80)\end{array}$ & $\begin{array}{c}-.51 \\
(-0.92)\end{array}$ & $\begin{array}{c}-.46 \\
(-1.08)\end{array}$ \\
\hline $\begin{array}{l}\text { Contract Holder: } \\
\text { respondent }\end{array}$ & & & & $\begin{array}{c}.66 \\
(2.54)\end{array}$ & \\
\hline $\begin{array}{l}\text { Contract Holder: } \\
\text { couple }\end{array}$ & & & & $\begin{array}{c}.58 \\
(2.01)\end{array}$ & \\
\hline $\begin{array}{l}\text { Contract Holder: } \\
\text { father/mother }\end{array}$ & & & & $\begin{array}{c}1.03 \\
(3.13)\end{array}$ & \\
\hline $\begin{array}{c}\text { Cheaper calls at certain } \\
\text { times }\end{array}$ & & $\begin{array}{c}-.22 \\
(-3.43)\end{array}$ & & & \\
\hline $\begin{array}{l}\text { Cheaper calls to } \\
\text { numbers chosen }\end{array}$ & $\begin{array}{c}.25 \\
(3.38)\end{array}$ & $\begin{array}{c}.20 \\
(3.10)\end{array}$ & $\begin{array}{c}.27 \\
(4.08)\end{array}$ & $\begin{array}{c}.30 \\
(3.42)\end{array}$ & $\begin{array}{c}.21 \\
(2.96)\end{array}$ \\
\hline $\begin{array}{l}\text { Has contracted mobile } \\
\text { broadband Internet }\end{array}$ & $\begin{array}{c}.75 \\
(3.93)\end{array}$ & & $\begin{array}{c}.55 \\
(3.67)\end{array}$ & $\begin{array}{c}.68 \\
(3.76)\end{array}$ & $\begin{array}{c}.55 \\
(3.85)\end{array}$ \\
\hline Expenditure & $\begin{array}{l}-.0058 \\
(-3.45)\end{array}$ & & & & \\
\hline Expenditure sq & $\begin{array}{l}.00001 \\
(2.46)\end{array}$ & & & & \\
\hline Spaniard & $\begin{array}{c}-.24 \\
(-2.12) \\
\end{array}$ & $\begin{array}{c}-.46 \\
(-4.92) \\
\end{array}$ & & & \\
\hline Age & & & & $\begin{array}{c}.02 \\
(4.93)\end{array}$ & \\
\hline Coverage problems & $\begin{array}{c}-.57 \\
(-6.22)\end{array}$ & $\begin{array}{c}-1.88 \\
(-21.83)\end{array}$ & $\begin{array}{c}-.59 \\
(-6.72)\end{array}$ & $\begin{array}{c}-.49 \\
(-4.23)\end{array}$ & $\begin{array}{c}-.62 \\
(-7.10)\end{array}$ \\
\hline $\begin{array}{l}\text { Incorrect } \\
\text { billing }\end{array}$ & $\begin{array}{c}-.24 \\
(-1.21)\end{array}$ & $\begin{array}{c}-.22 \\
(-1.22)\end{array}$ & $\begin{array}{c}-12 \\
(-0.58)\end{array}$ & $\begin{array}{c}-.18 \\
(-0.73)\end{array}$ & $\begin{array}{c}-.56 \\
(-2.48)\end{array}$ \\
\hline $\begin{array}{l}\text { Incorrect billing for } \\
\text { services not used }\end{array}$ & $\begin{array}{c}-.44 \\
(-2.09)\end{array}$ & $\begin{array}{c}-.13 \\
(0-68)\end{array}$ & $\begin{array}{c}-.40 \\
(-2.04)\end{array}$ & $\begin{array}{c}-.23 \\
(-0.86)\end{array}$ & $\begin{array}{c}-.37 \\
(-1.84)\end{array}$ \\
\hline $\begin{array}{l}\text { Breach of contract or } \\
\text { commercial offer }\end{array}$ & $\begin{array}{c}-.51 \\
(-2.20)\end{array}$ & $\begin{array}{c}-.22 \\
(-1.12)\end{array}$ & $\begin{array}{c}-.68 \\
(-2.77)\end{array}$ & $\begin{array}{c}-.58 \\
(-2.15)\end{array}$ & $\begin{array}{c}-.51 \\
(-2.09)\end{array}$ \\
\hline $\begin{array}{l}\text { Difficulty in cancelling } \\
\text { the service }\end{array}$ & $\begin{array}{c}-.65 \\
(-2.67)\end{array}$ & $\begin{array}{c}-.21 \\
(-0.88)\end{array}$ & $\begin{array}{c}-.29 \\
(-1.09)\end{array}$ & $\begin{array}{c}-.59 \\
(-2.02)\end{array}$ & $\begin{array}{c}-.46 \\
(-1.76)\end{array}$ \\
\hline $\begin{array}{l}\text { Difficulty in obtaining } \\
\text { the required info. }\end{array}$ & $\begin{array}{c}-1.00 \\
(-6.40)\end{array}$ & $\begin{array}{c}-.02 \\
(-0.14)\end{array}$ & $\begin{array}{l}-1.03 \\
(-6.23) \\
\end{array}$ & $\begin{array}{c}-1.05 \\
(-5.15)\end{array}$ & $\begin{array}{c}-.61 \\
(-3.63) \\
\end{array}$ \\
\hline $\begin{array}{l}\text { +16 dummies for A.C. } \\
\text { F (p-value) }\end{array}$ & $\begin{array}{c}F(16,3105)= \\
10.12 \\
(0.0000)\end{array}$ & $\begin{array}{c}\mathrm{F}(16,3506)= \\
5.46 \\
(0.0000)\end{array}$ & $\begin{array}{c}F(16,3250)= \\
8.81 \\
(0.0000)\end{array}$ & $\begin{array}{c}\mathrm{F}(16,2253)= \\
8.64 \\
(0.0000)\end{array}$ & $\begin{array}{c}F(16,2684)= \\
10.60 \\
(0.0000)\end{array}$ \\
\hline Constant & $\begin{array}{c}7.64 \\
(28.33) \\
\end{array}$ & $\begin{array}{c}7.75 \\
(30.33) \\
\end{array}$ & $\begin{array}{c}7.11 \\
(29.47) \\
\end{array}$ & $\begin{array}{c}5.47 \\
(11.07) \\
\end{array}$ & $\begin{array}{c}6.46 \\
(22.44) \\
\end{array}$ \\
\hline Number of Outliers & 2 & 33 & 16 & 27 & 24 \\
\hline $\begin{array}{c}\mathrm{F} \\
\text { (p-value) }\end{array}$ & $\begin{array}{c}13.90 \\
(0.0000)\end{array}$ & $\begin{array}{l}120.27 \\
(0.0000)\end{array}$ & $\begin{array}{c}65.40 \\
(0.0000)\end{array}$ & $\begin{array}{c}40.39 \\
(0.0000)\end{array}$ & $\begin{array}{c}24.16 \\
(0.0000)\end{array}$ \\
\hline White test, $\chi^{2}$ & 92.24 & 95.05 & 96.17 & 123.36 & 63.04 \\
\hline $\mathrm{R}^{2}$ & 0.1371 & 0.2743 & 0.1523 & 0.1900 & 0.1912 \\
\hline $\mathrm{n}$ & 3009 & 3360 & 3136 & 2186 & 2603 \\
\hline
\end{tabular}

Notes: Using heteroskedasticity consistent covariance matrix estimator (Eicker-White) 